\title{
39. SEISMIC STRATIGRAPHY OF THE NEOGENE SEQUENCE AT SITE 587
}

\author{
Alain Mignot and Alain Mauffret, Département de Géologie Dynamique, Université Pierre et Marie Curie²
}

\section{INTRODUCTION}

The Lord Howe Rise terminates northward against the southeast-trending Fairway Ridge. The Fairway Basin lies to the south of this juncture between the Fairway Ridge and the Lord Howe Rise. Eastward off the Fairway Ridge lies the New Caledonia Basin. Lansdowne Bank, a $137-\mathrm{km}$-long, 50-km-wide fossil atoll, lies on the northern termination of the Lord Howe Rise at the juncture with the Fairway Ridge (Fig. 1).

These local submarine ridges are isolated from terrigenous input from Australia to the west and New Caledonia to the east. Consequently, they are mantled by undiluted Neogene pelagic sedimentation that records Neogene paleooceanography.

The Comité d'Etudes Pétrolières Marines undertook a seismic investigation in 1981 using two Institut Français du Pétrole Flexichoc sound sources and a 48-trace seismic streamer. Data were processed 24 -fold. This survey led to the siting of DSDP Site 587 of Leg $90\left(21^{\circ} 11^{\prime}\right.$ S, $161^{\circ} 21^{\prime} \mathrm{E}$; see Site 587 site chapter, this vol.). This 3000 $\mathrm{km}$ survey is not a dense grid; there are about $50-\mathrm{km}$ between each profile. Nevertheless, prior seismic information in this area is scarce (Dubois et al., 1974; Ravenne et al., 1977).

\section{SEISMIC FACIES ANALYSIS AND INTERPRETATION OF THE TRANSPARENT SEISMIC FACIES}

The Neogene sequence is thin (about $300 \mathrm{~m}$ thick) on top of the ridges, and the low amplitude of reflections from within the sediment sequence suggests a degree of homogeneity in the deposits (Fig. 2, location A). The topographic isolation of the region and shallow-water depth suggest that the most important constituent of the sediment section is calcareous pelagic sediments. These pelagic sediments are reworked by bottom currents that follow small channels (Fig. 2, location B). In the basin along the base of the ridge, the Neogene sequence infills a tilted-block topography. Some high-amplitude reflections indicate that detrital sediments are ponded in these topographic basins (Fig. 3, location A).

\section{SEISMIC FACIES AROUND THE LANSDOWNE BANK}

Along the western flank of Lansdowne Bank, chaotic seismic facies suggest that some combination of slump-

\footnotetext{
${ }^{1}$ Kennett, J. P., von der Borch, C. C., et al., Init. Repts. DSDP, 90: Washington (U.S. Govt, Printing Office).

2 Address: Groupe d'Etude de la Marge Continentale (ERA 605 du CNRS), Département de Géologic Dynamique, Université Pierre et Marie Curie, 4, place Jussieu, 75230. Paris, Cedex 05, France.
}

ing and canyon erosion are the main sedimentary processes acting at present (Fig. 4, location A). Interbedded strong reflections (Fig. 4, location B), however, make the section appear similar to the basal sequence of the Rhône deep-sea fan (Droz, 1982) and indicate intermittent deposition. In this area the deposits are rare and unstable. Downslope, a fan is formed by the coalescing of sedimentary wedges deposited at the mouths of several canyons. The main channel of the fan is bounded by asymmetrical levees (Fig. 5, locations A and B). Discontinuous reflections within the channel levees indicate an environment of deposition in which presumed finegrained sediments settle out of turbidity currents while the main channel continues to be the locus of transport and erosion (Mullins et al., 1984).

In the distal parts of the fan, the levee and channel system becomes attenuated (Fig. 6). There possible medium-sized particles and fine-grained sands are deposited among a system of laterally migrating channels (Fig. 6, features labeled B). The seismic facies is typically linked to buried channels and levees. The detrital fraction that passes through the canyons and channels is probably bioclastic material: coral and other neritic remains from Lansdowne Bank.

At the far distal portions of the fan the seafloor becomes flat and shows little evidence of channels (Fig. 7). The pelagic material (the transparent seismic facies) is interbedded with turbidites, and the composite produces a seismic facies characterized by low-frequency reflections of variable amplitude.

\section{EVOLUTION OF THE NEOGENE SEQUENCE}

The Neogene section overlies an Oligocene discontinuity (Fig. 8, horizon A) (Mignot, 1984). The basal Neogene is a seismically transparent layer that onlaps horizon A to the northwest (Fig. 8, location E) and is overlain in turn by a series of strong, discontinuous reflections (Fig. 8, location D). The contrasting seismic character probably reflects basal Neogene deposition of homogeneous, fine-grained sediments that become interbedded upward with sandy layers originating from erosion of the Lansdowne Bank. Some channels can be observed (Fig. 8, locations B and C). Assuming a relatively constant sedimentation rate and knowing the sequence thickness and the depth of drilling at Site 587, we estimate the lowest layer of sandy deposits to be late Oligocene to early Miocene in age.

\section{SEISMIC CHARACTER OF SEDIMENTS AT SITE 587}

Site 587 was chosen to obtain an uncomplicated, highresolution record in calcareous sediments of Neogene age 


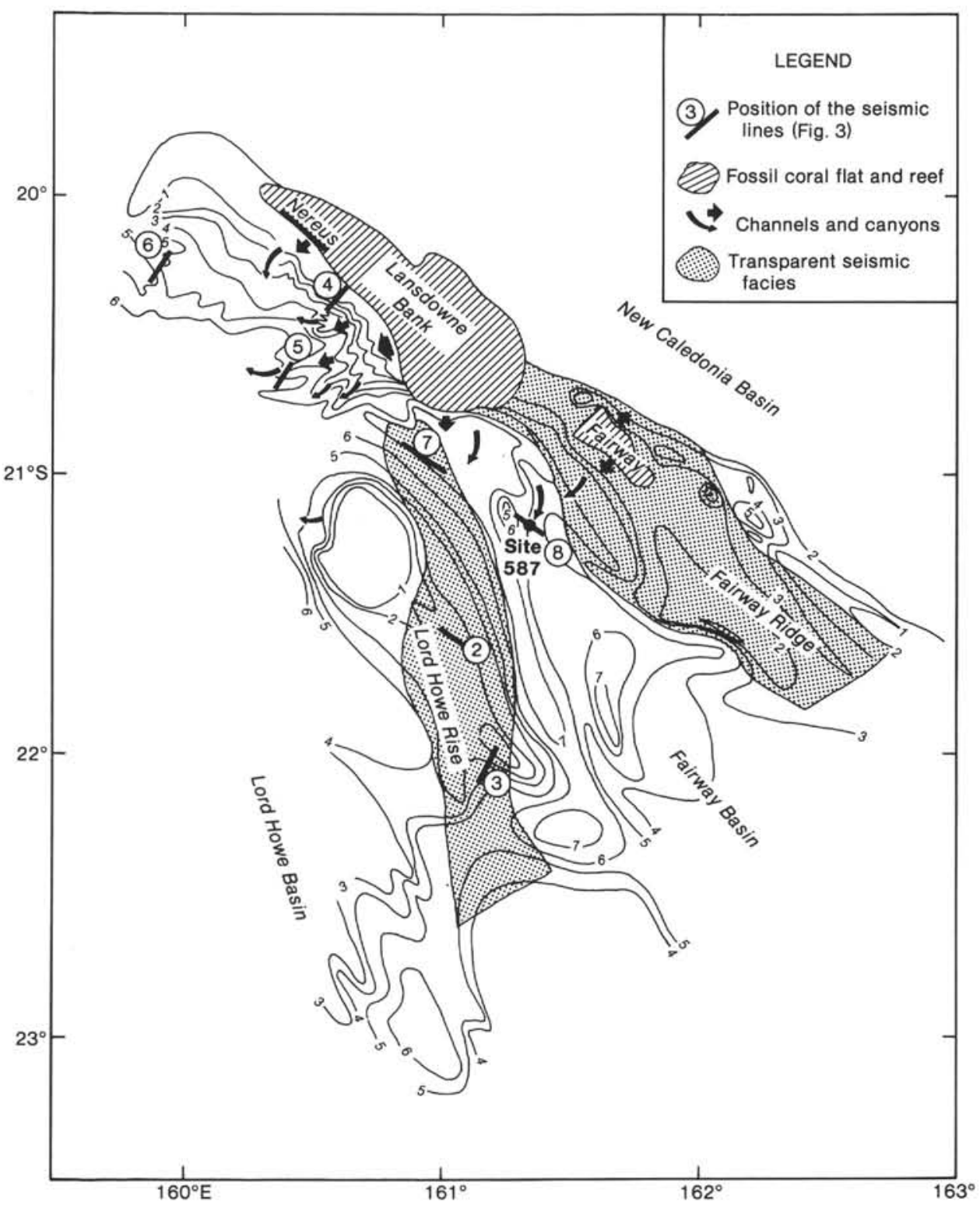

Figure 1. Isochron map ( $0.1 \mathrm{~s}$ two-way traveltime) of the Neogene sequence in the area of the northern termination of Lord Howe Rise. Circled numbers refer to figure numbers in this article, which are seismic lines taken at these locations.

NW

$5 \mathrm{~km}$

SE

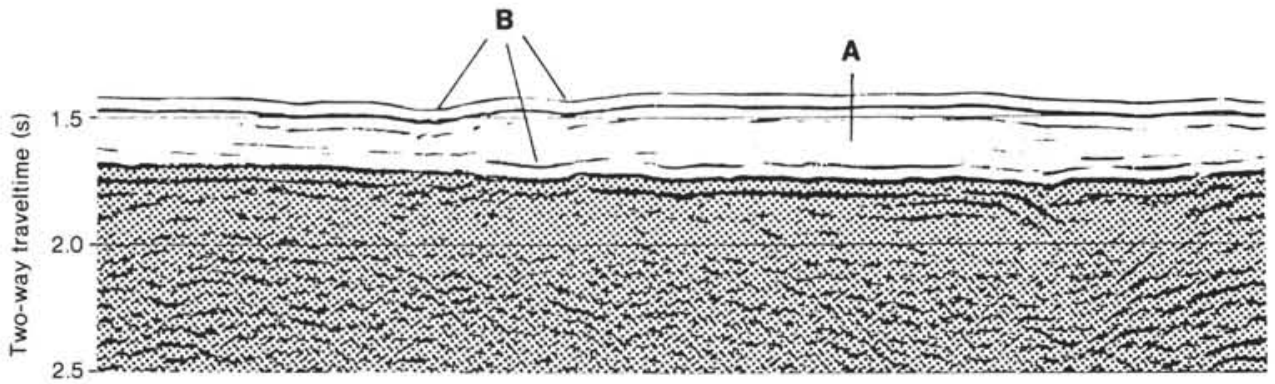

Figure 2. Seismic section showing transparent facies on the Lord Howe Rise. A. Transparent facies. B. Small channels. (For position refer to Fig. 1.) 


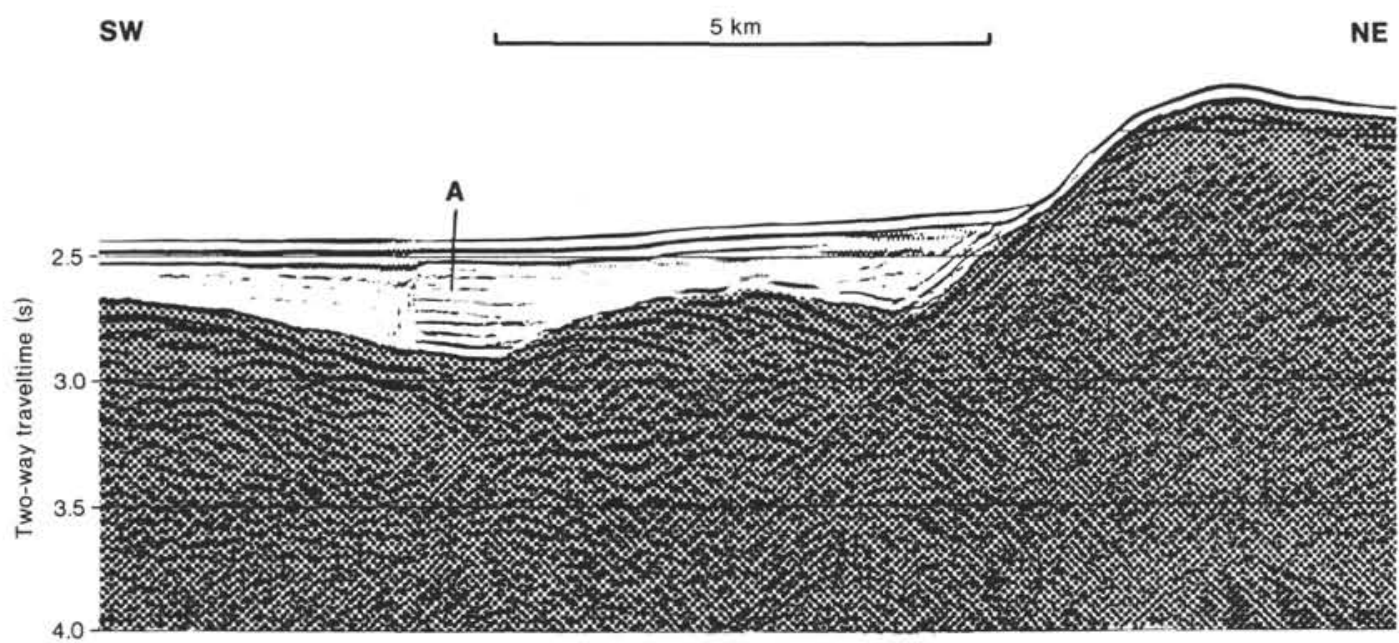

Figure 3. Seismic section showing a transparent layer on the Lord Howe Rise infilling a tilted-block topography. A. Depression infilled with sediments that are coarser than in the surrounding area. (For position refer to Figure 1.)

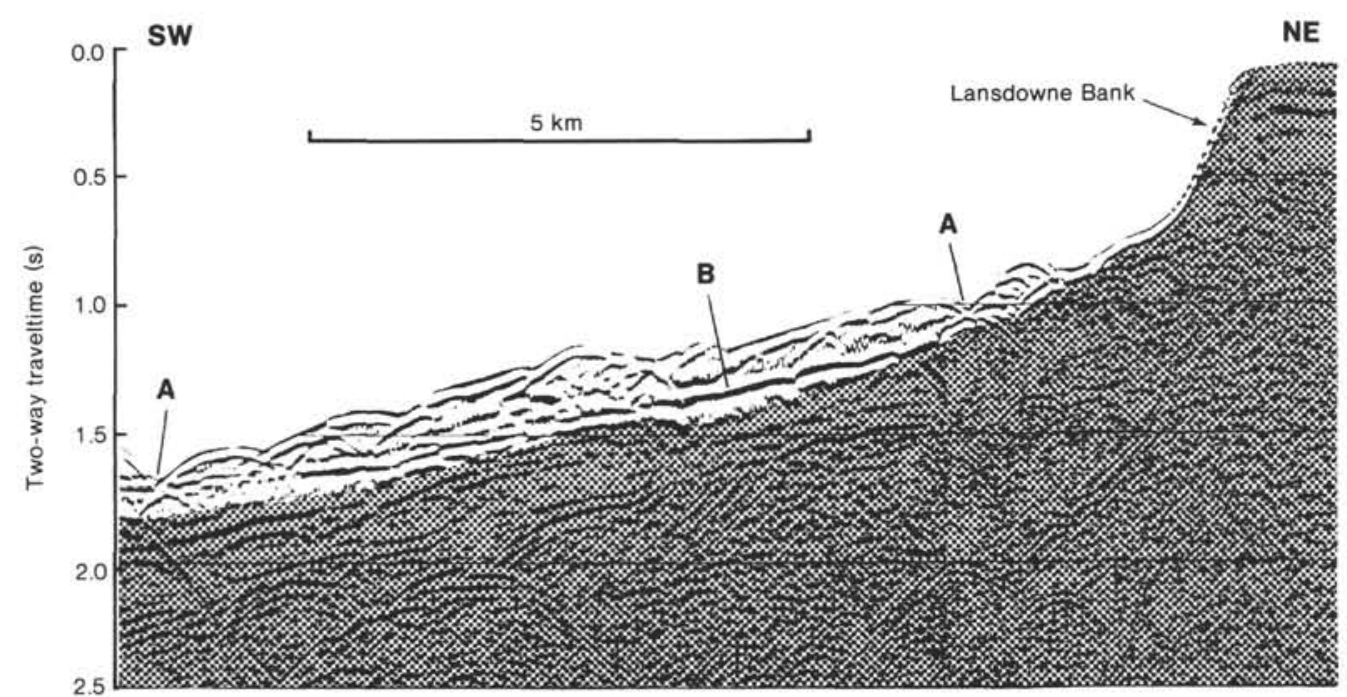

Figure 4. Seismic section showing the western slope of Lansdowne Bank, where slumping and erosion has occurred. (For position refer to Figure 1.) A. Slumps and erosion; B. Interbedded strong reflection.

sw $5 \mathrm{~km}$

NE

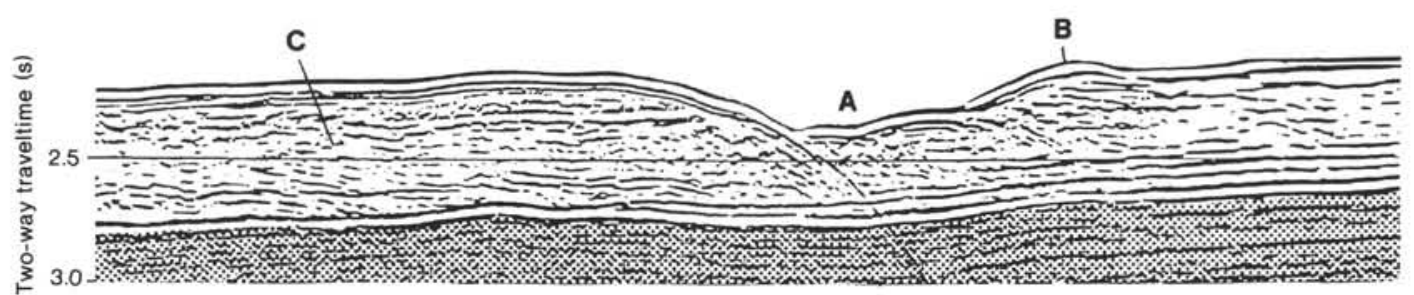

Figure 5. Seismic section showing channels in the fan off Lansdowne Bank. A. Channel. B. Levee. C. Discontinuous reflector indicating high-energy environment. (For position refer to Figure 1.)

between the warm subtropics and the equatorial zone. Unfortunately, Site 587 was located in a channel where detrital sediments from Lansdowne Bank (located upslope) accumulated. This channel could have been avoided if different displays of the seismic data had been consulted. Figure 9 shows the data before and after deconvolution. Deconvolution in this case has obliterated the obvious channel that appears in the seismic section prior to deconvolution.

\section{CONCLUSION}

The flank of Lansdowne Bank is a typical bypass carbonate slope that is located upslope from a carbonate fan (Ravenne et al., 1985); Schlager and Ginsburg, 1981). 


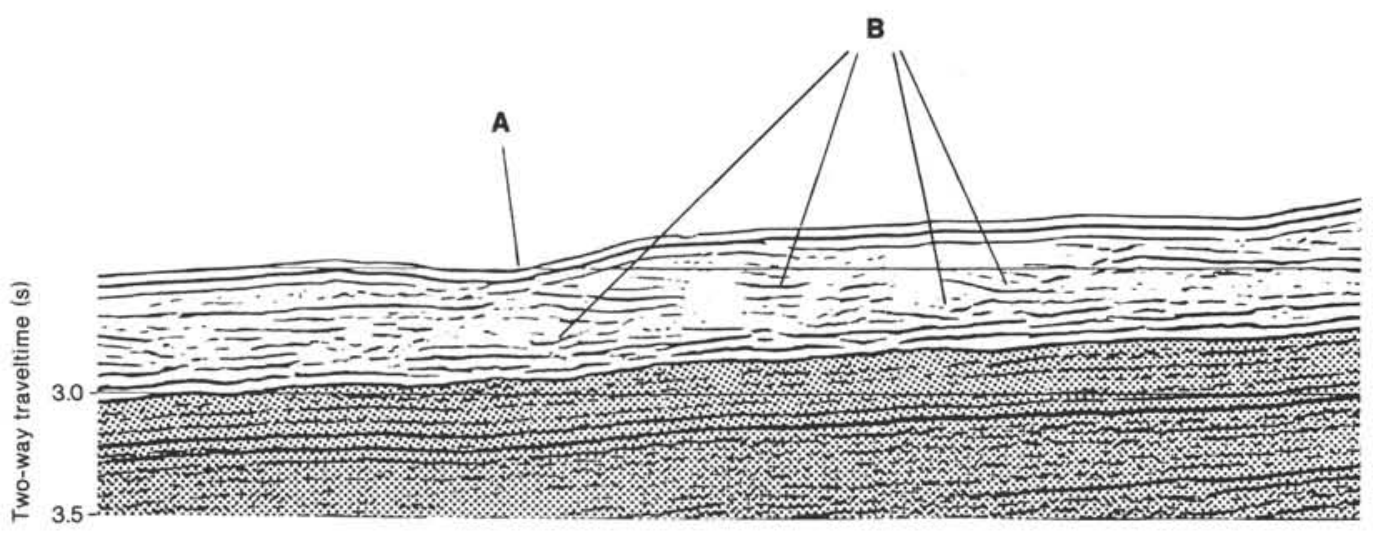

Figure 6. Seismic section showing a small channel in the distal part of the fan. A. Channel. B. Buried channels. (For position refer to Figure 1.)

NW

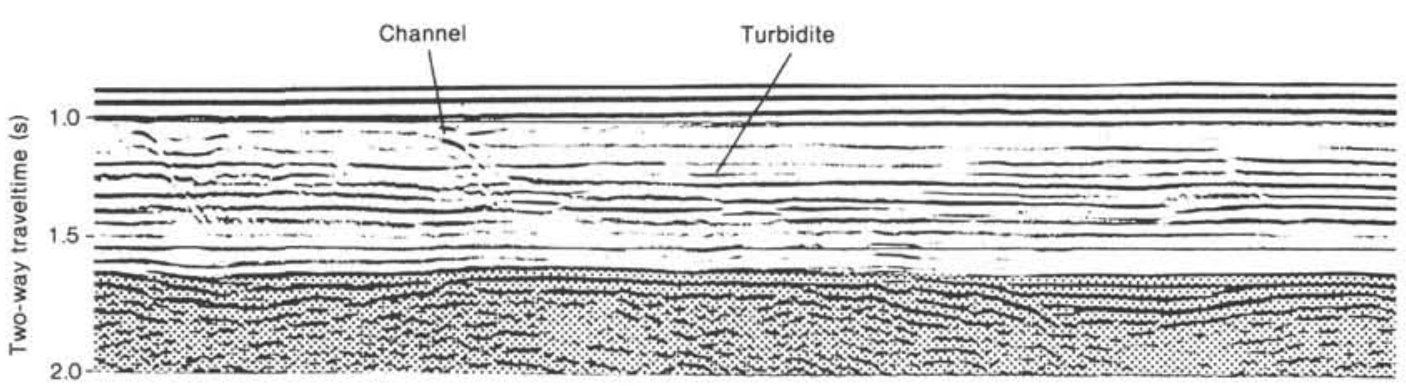

Figure 7. Seismic section showing turbidites interbedded in pelagic sediments south of Lansdowne Bank. (For position refer to Figure 1.)

Site 587 was drilled in a channel where the probability of encountering gravel and sand was high. This explains why only $60 \%$ of the cores were recovered and why the hole was abandoned.

\section{ACKNOWLEDGMENTS}

We thank the C.E.P.M., which provided and processed the seismic data. We appreciate the many constructive comments on early drafts of the manuscripts by J. Ladd. We also thank J. Ladd and A. Beck for translation and corrections.

\section{REFERENCES}

Droz, L., 1983. L'éventail sous-marin profond du Rhône (Golfe du Lion): grands traits morphologiques et structure semi-profonde. Thèse 3e cycle, Université Pierre et Marie Curie, Paris.

Dubois, J. Ravenne, C., Aubertin, A., Louis, J., Guillaume, R., Launay, J., and Montadert, L., 1974. Continental Margins near New Caledonia. In Burk, C. A., and Drake C. L. (Eds.), The Geology of Continental Margins: New York/Berlin (Springer Verlag), pp. 521-535.
Mignot, A., 1984. Sismo-stratigraphie de la terminaison nord de la ride de Lord Howe. Evolution géodynamique du Sud-Ouest Pacifique entre l'Australie et la Nouvelle-Calédonie. Thèse 3e Cycle, University, Pierre et Marie Curie, Paris.

Mullins, H. T., Heath, W. C., Van Buren, M., and Newton, C. R., 1984. Anatomy of a modern open ocean carbonate slope: northern Little Bahama Bank. Sedimentology, 31:141-168.

Ravenne, C., de Broin, C. E., Dupont, J., Lapouille, A., and Launay, J., 1977. New Caledonia basin-Fairway Ridge: structural and sedimentary study. International Symposium on Geodynamics in SouthWest Pacific, Nouméa 1976: Paris (Technip), pp. 145-154.

Ravenne, C., Le Quellec, P., and Valery, P., 1985. Dépôts carbonatés profonds des Bahamas. Géodynamique des Caraibes; Symposium, Paris 5, 8 février 1985: Paris (Technip), pp. 255-270.

Schlager, W., and Ginsburg, R. N., 1981. Bahama Carbonate Platforms: the deep and the past. Mar. Geol. 44:1-24.

Date of Initial Receipt: 1 November 1984 Date of Acceptance: 22 April 1985 


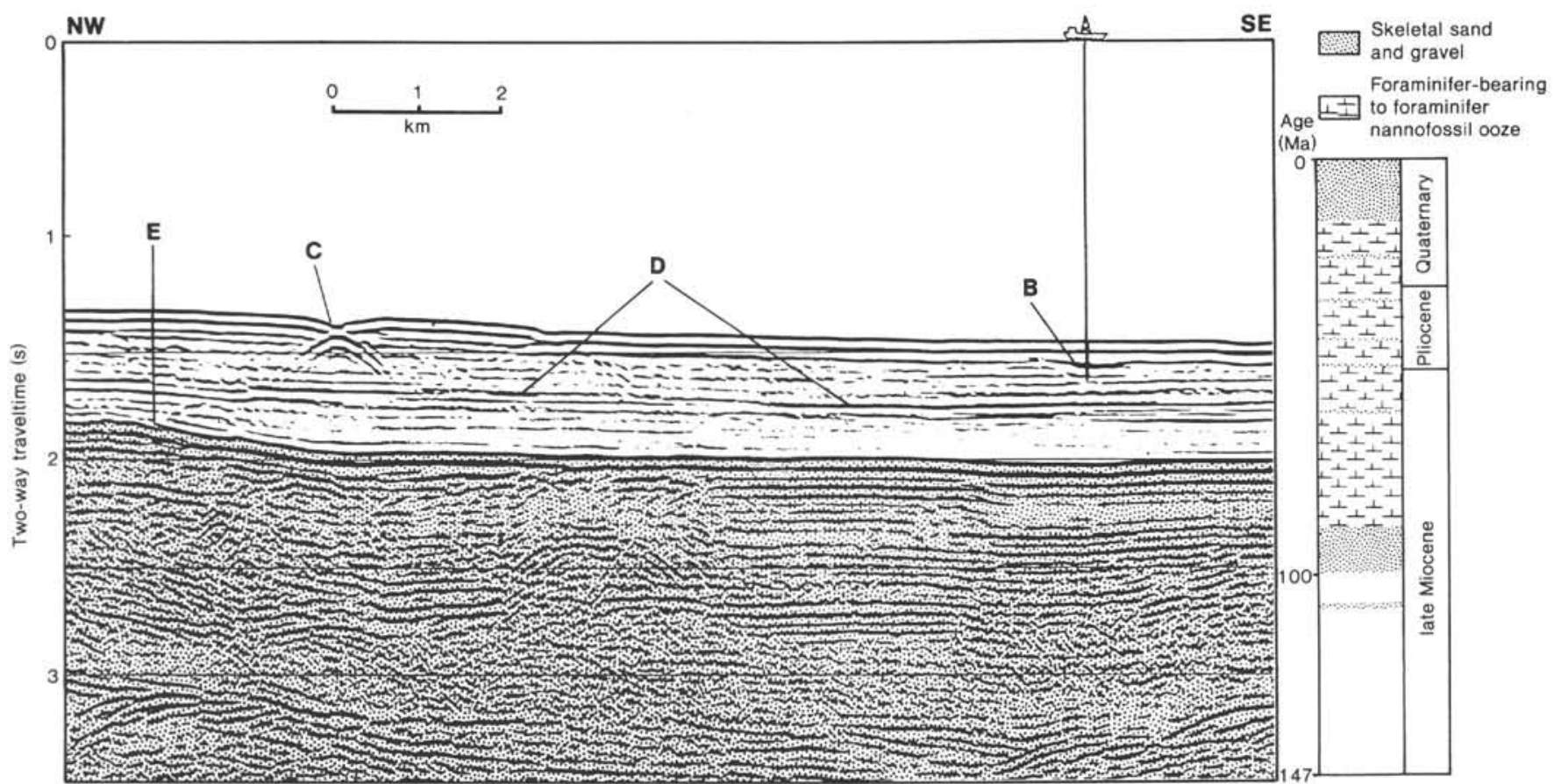

Figure 8. Seismic profile and stratigraphic section in the area of Site $587\left(21^{\circ} 11^{\prime} \mathrm{S}, 161^{\circ} 20^{\prime} \mathrm{E}\right)$. A. Oligocene unconformity. B. Buried channel: C. Channel. D. Discontinuous reflections of late Oligocene to early Miocene age. E. Bottom lap. (For position refer to Figure 1.) Areas of no recovery left blank in stratigraphic column. 


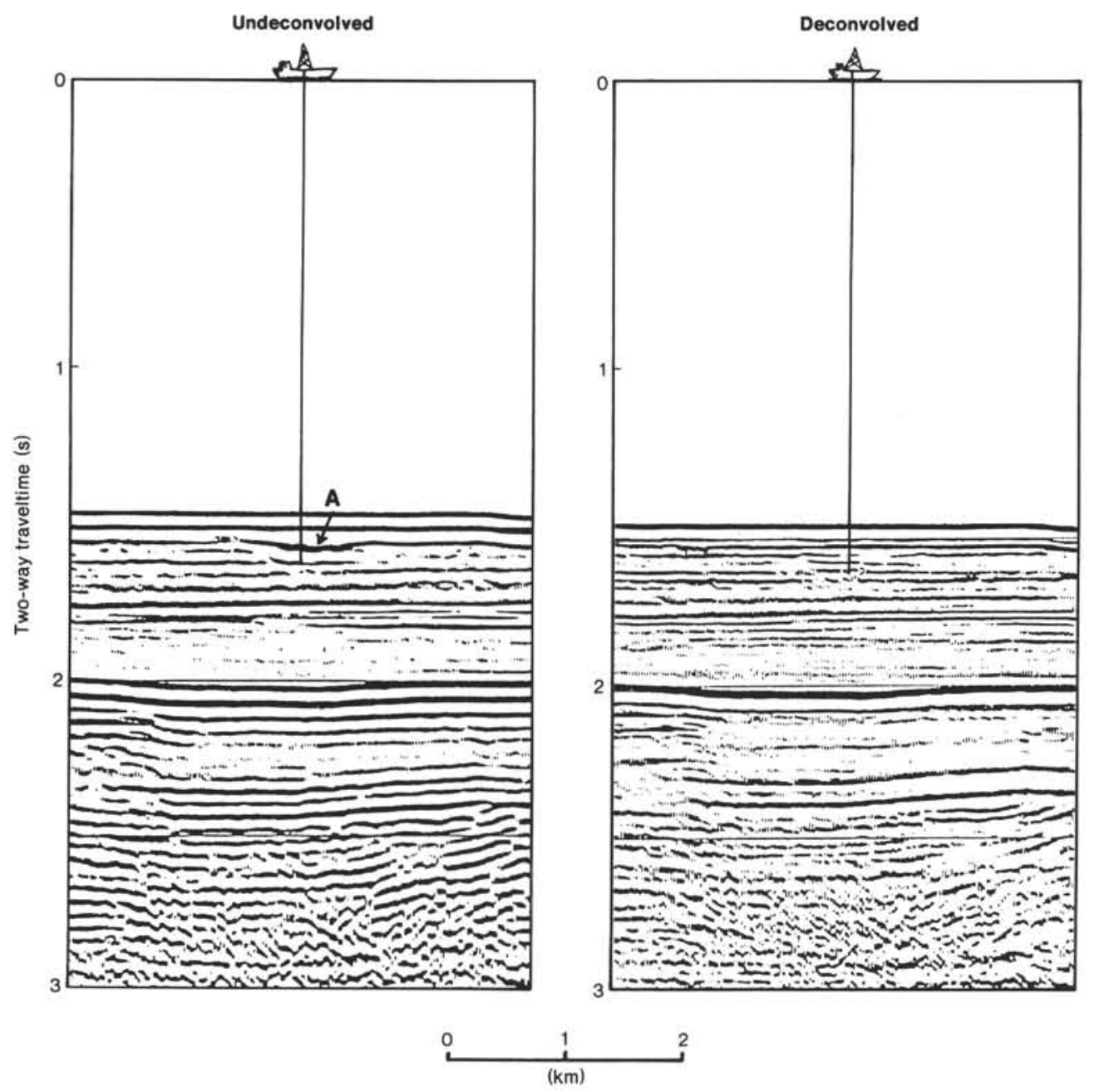

Figure 9. Comparison between the undeconvolved seismic section (left) and the deconvolved seismic section (right). Note the channel (A) in the left section that disappears in the right section. (For position refer to Figure 1.) 